\title{
Keamanan Vaksin Dengue pada Anak
}

\author{
Hindra Irawan Satari, Sharfina Fulki Adilla H \\ Departemen Ilmu Kesehatan Anak Fakultas Kedokteran Universitas Indonesia/RSUP Dr. Cipto Mangunkusumo, Jakarta
}

Latar belakang. Insidens dengue meningkat 30 kali lipat dalam 50 tahun terakhir. Penemuan vaksin dengue diharapkan dapat menurunkan angka ini. Vaksin dengue telah mendapatkan izin edar di 19 negara di dunia pada tahun 2015 dan di Indonesia pada tahun 2016. Pada tahun 2017, produsen vaksin menyatakan terdapat kemungkinan dengue berat pada pasien yang belum pernah terinfeksi dengue sebelumnya. Tahun yang sama, Filipina melaporkan tiga kasus kematian terkait dengan vaksin dengue. Hal tersebut menimbulkan keresahan di masyarakat mengenai profil keamanan vaksin dengue.

Tujuan. Mengetahui keamanan vaksin dengue untuk individu seronegatif dengan usia $\geq 9$ tahun.

Metode. Penelusuran pustaka database elektronik, yaitu Pubmed dan Cochrane.

Hasil. Studi oleh Garcia dkk, memperoleh bahwa risiko relatif rawat inap karena dengue yang terkonfirmasi secara virologis pada resipien seronegatif usia $\geq 9$ tahun adalah 0,937 (IK95\% 0,24-4,37). Studi lainnya yaitu, Shridar dkk, suatu case-cohort, mendapatkan hal yang sama yaitu risiko rawat inap karena dengue pada resipien seronegatif adalah 1,41 (IK95\% 0,74-2,68), dan untuk dengue berat 2,44 (IK95\% 0,47-12,56). Keduanya memberikan hasil yang tidak signifikan.

Kesimpulan. Pemberian vaksin dengue pada individu seronegatif $\geq 9$ tahun tidak mempengaruhi risiko rawat inap dan dengue berat secara signifikan. Sari Pediatri 2019;21(2):129-37

Kata kunci: anak, vaksin dengue, rawat inap, dengue berat

\section{Dengue Vaccine Safety in Children}

Hindra Irawan Satari, Sharfina Fulki Adilla H

Background. The incidence of dengue has increased 30 fold over the last 50 years. The discovery of dengue vaccine is expected to reduce this number. This vaccine has been registered in 19 countries by 2015 and in Indonesia in 2016. In 2017, vaccine manufacturers stated that "For those not previously infected by dengue virus, however, the analysis found that in the longer term, more cases of severe disease could occur following vaccination upon a subsequent dengue infection". At the same year, Philippines reported three deaths related to the dengue vaccine. This has caused vaccine hesistency in community regarding safety profile of dengue vaccine.

Objective. To describe the safety profile of dengue vaccine in seronegative individuals aged nine years and above.

Method. Electronic literature searches using Pubmed and Cochrane.

Results. The study by Garcia et al, found that the risk of hospitalization due to virologically confirmed dengue in the seronegative recipient aged $\geq 9$ years was 0.937 (CI 95\% 0.24-4.37). Another study, Shridar et al, a case-cohort study, found the risk of hospital admission for virologically confirmed dengue and the risk of clinically severe dengue in those aged $\geq 9$ years was 1.41 (CI $95 \% 0.74-$ 2.68), and 2.44 (CI 95\% 0,47-12,56), respectively. Both provide insignificant results.

Conclusion. Giving dengue vaccine to seronegative individuals aged nine years and above did not significantly affect the risk of hospitalization and severe dengue. Sari Pediatri 2019;21(2):129-37

Keywords: pediatric, dengue vaccine, virologically confirmed dengue and severe dengue

Alamat korespondensi: Hindra Irawan Satari. Departemen Ilmu Kesehatan Anak Fakultas Kedokteran Universitas Indonesia/ RSUP Dr. Cipto Mangunkusumo, Jakarta. Email: hsatari54@yahoo.com 


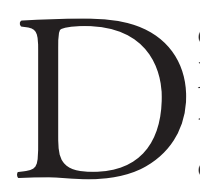
engue merupakan salah satu masalah kesehatan masyarakat utama di wilayah tropis dan sub-tropis di dunia. ${ }^{1}$ Insidens dengue dalam 50 tahun terakhir meningkat hingga 30 kali lipat. ${ }^{2}$ Epidemi dengue menyebabkan morbiditas dan mortalitas yang tinggi, serta dampak sosial dan kerugian ekonomi yang sangat besar. ${ }^{1}$ World Health Organization (WHO) menargetkan penurunan angka mortalitas akibat dengue sebesar $\geq 50 \%$ dan morbiditas $\geq 25 \%$ pada tahun 2020 .

Indonesia merupakan salah satu negara di Asia dengan endemisitas dengue A. Data tahun 2014 memperlihatkan jumlah kasus dengue di Indonesia sekitar 100.437 kasus dengan angka kesakitan 39,8 dan angka kematian 900 per 100.000 penduduk. ${ }^{3}$ Tindakan pencegahan telah difokuskan pada pengendalian vektor, pendidikan, dan perubahan perilaku untuk mengurangi interaksi antara manusia dan nyamuk vektor. Perbaikan manajemen tata laksana dan kesadaran masyarakat berkontribusi pada penurunan angka kematian hingga di bawah satu persen, namun insidens keseluruhan dengue terus meningkat. ${ }^{4}$ Pengembangan vaksin yang dapat mencegah infeksi keempat serotipe dengue merupakan salah satu prioritas kesehatan di negara endemis.

Pada tahun 2011, penelitian Sanofi Pasteur mengenai vaksin hidup, chimeric yellow fever tetravalent dengue vaccine (CYD-TDV) memasuki fase III uji klinis. Vaksin ini dikaji efikasi dan keamanannya di 25 uji klinis, di 15 negara, dengan lebih dari 30.000 partisipan usia 2-16 tahun. ${ }^{5,6}$ Bulan Desember tahun 2015, vaksin ini pertama kalinya mendapat lisensi di Meksiko, Brazil dan Filipina, dan selanjutnya di 19 negara Asia, Amerika Latin dan Australia. ${ }^{7}$ Tahun 2016, WHO Strategic Advisory Group of Experts on Immunization (SAGE) merekomendasikan penggunaan vaksin dengue hanya pada anak usia $\geq 9$ tahun di negara endemis (seroprevalens) $>70 \%$, dan tidak direkomendasikan jika seroprevalens $<50 \%$. ${ }^{8}$

Pada tahun 2018, salah satu rumah sakit di Filipina menyatakan tiga resipien vaksin meninggal enam bulan sampai satu tahun setelah injeksi vaksin terkait dengue. Food and Drug Administration (FDA) menarik sementara izin edar, penjualan dan distribusi Dengvaxia $^{\circledR}$ di Filipina. Bulan April 2018, WHO SAGE merevisi rekomendasi penggunaan CYD-TDV yang menitikberatkan skrining pre-vaksinasi. ${ }^{9}$

Ikatan Dokter Anak Indonesia (IDAI) menerbitkan rekomendasi vaksin dengue pada tahun 2017 yaitu pemberian vaksin tiga kali dengan interval enam bulan, pada anak usia 9-16 tahun. ${ }^{3}$ Terkait pernyataan mengenai keamanan vaksin oleh produsen, bulan Desember 2017, IDAI menginstruksikan dokter anak Indonesia untuk menangguhkan pemberian vaksin dengue. Badan Pengawas Obat dan Makanan Republik Indonesia (BPOM RI) mengeluarkan izin edar vaksin dengue sejak 31 Agustus 2016 dan berlaku hingga tahun 2021. Beberapa adendum mengenai informasi produk disetujui dan rekomendasi ditambahkan, yaitu vaksin dengue hanya digunakan untuk mengurangi risiko kejadian dan keparahan demam berdarah dengue pada anak usia 9-16 tahun yang sebelumnya pernah terinfeksi virus tersebut, dan tidak boleh digunakan pada individu yang belum pernah terinfeksi. ${ }^{10}$ Departemen Kesehatan Indonesia tidak mengeluarkan pernyataan mengenai isu tersebut. Laporan kasus berbasis bukti ini bertujuan untuk mengkaji keamanan vaksin dengue.

\section{Ilustrasi kasus}

Seorang anak laki-laki, 14 tahun, datang ke Instalasi Gawat Darurat (IGD) dengan demam tinggi sejak dua hari sebelum masuk rumah sakit (SMRS). Suhu puncak $39,3^{\circ} \mathrm{C}$. Pasien mengeluh nyeri kepala disertai dengan nyeri otot. Tidak terdapat bintik-bintik kemerahan pada tubuh, mimisan, buang air kecil (BAK) berdarah dan muntah darah. Pasien merasakan juga nyeri ulu hati dan mual. Pasien belum pernah terkena demam dengue atau demam berdarah dengue sebelumnya. Tiga tahun lalu (usia 11 tahun) pasien sudah mendapat vaksin dengue sebanyak tiga dosis dengan interval enam bulan.

Pemeriksaan fisis menunjukkan kesadaran pasien kompos mentis, laju nadi $74 \mathrm{kali} / \mathrm{menit}$, nadi kuat, regular, dan laju napas $20 \mathrm{kali} / \mathrm{menit}$. Tekanan darah 110/70 mmHg (p50-p90) dengan suhu 38,8 derajat celcius. Konjungtiva tidak anemis, mukosa basah, pemeriksaan jantung dan paru dalam batas normal. Terdapat nyeri tekan di daerah epigastrium, tidak ditemukan hepatosplenomegali dan petekie. Pemeriksaan antropometri menunjukkan gizi baik, perawakan normal dengan $\mathrm{BB} / \mathrm{U} 83 \%$, TB/U 93\%, dan BB/TB 93\%.

Hasil pemeriksaan laboratorium saat awal menunjukkan hemoglobin $(\mathrm{Hb}) 15 \mathrm{~g} / \mathrm{dL}$ dengan hematokrit $(\mathrm{Ht}$ ) 47\%, leukosit 5.900/uL, trombosit 266.000/uL, serum glutamic oxaloacetic transaminase 
(SGOT) $29 \mathrm{U} / 1$, serum glutamic pyruvic transaminase (SGPT) $14 \mathrm{U} / 1$, anti non-structural protein (NS) 1 positif, IgG dan IgM anti-dengue negatif. Selama perawatan tidak ditemukan tanda kebocoran plasma pada pasien. Diagnosis pasien adalah demam dengue.

\section{Pertanyaan klinis}

Berdasarkan ilustrasi kasus di atas, muncul pertanyaan klinis sebagai berikut: Bagaimana keamanan pemberian vaksin dengue pada anak $\geq 9$ tahun tanpa infeksi primer sebelumnya?

\section{Metode}

Pencarian dilakukan melalui Pubmed dan Cochrane pada bulan April 2019. Alat pencarian digunakan dengan kata kunci "pediatric OR children" AND "dengue vaccine" AND "safety" (Tabel 3). Strategi pencarian, hasil, kriteria inklusi dan ekslusi serta seleksi ditunjukkan melalui diagram alur (Gambar 1). Dua artikel relevan ditelaah dengan memerhatikan validitas, kepentingannya dam penerapannya pada pasien (Tabel 3). Daftar tilik yang digunakan diperoleh dari https:// www.cebm.net/2014/06/critical-appraisal/.

Tabel 1. Data pemantauan laboratorium pasien

\begin{tabular}{lccccc}
\hline Hari perawatan & ke- 2 & ke-3 & ke-4 & ke-5 & ke-6 \\
\hline $\mathrm{Hb}(\mathrm{g} / \mathrm{dL})$ & 14,6 & 14,9 & 15,1 & 15,4 & 15,3 \\
$\mathrm{Ht}(\%)$ & 44 & 42,2 & 43,5 & 45,9 & 46,4 \\
Leukosit $(/ \mathrm{uL})$ & 4000 & 3300 & 4000 & 5400 & 5400 \\
Trombosit $(/ \mathrm{uL})$ & 181.000 & 131.000 & 109.000 & 123.000 & 147.000 \\
\hline
\end{tabular}

Tabel 2. PICO

\begin{tabular}{lccc}
\hline Populasi $(\mathrm{P})$ & Intervensi $(\mathrm{I})$ & Pembanding $(\mathrm{C})$ & Hasil $(\mathrm{O})$ \\
\hline $\begin{array}{l}\text { Anak usia } \geq 9 \text { tahun tanpa } \\
\text { infeksi primer }\end{array}$ & Vaksin dengue & Tidak diberikan vaksin & $\begin{array}{c}\text { Keamanan (infeksi dengue, } \\
\text { dengue berat) }\end{array}$ \\
\hline
\end{tabular}

Tabel 3. Strategi pencarian yang dilakukan melalui Pubmed dan Cochrane

\begin{tabular}{lcc}
\hline Portal pencarian & Kata kunci & Artikel yang didapat \\
\hline Pubmed & pediatric, OR children, AND dengue vaccine, & 84 \\
Cochrane & AND safety $[$ MeSH Terms $]$ \\
& pediatric OR children, AND dengue vaccine, \\
AND safety $[$ MeSH Terms $]$
\end{tabular}

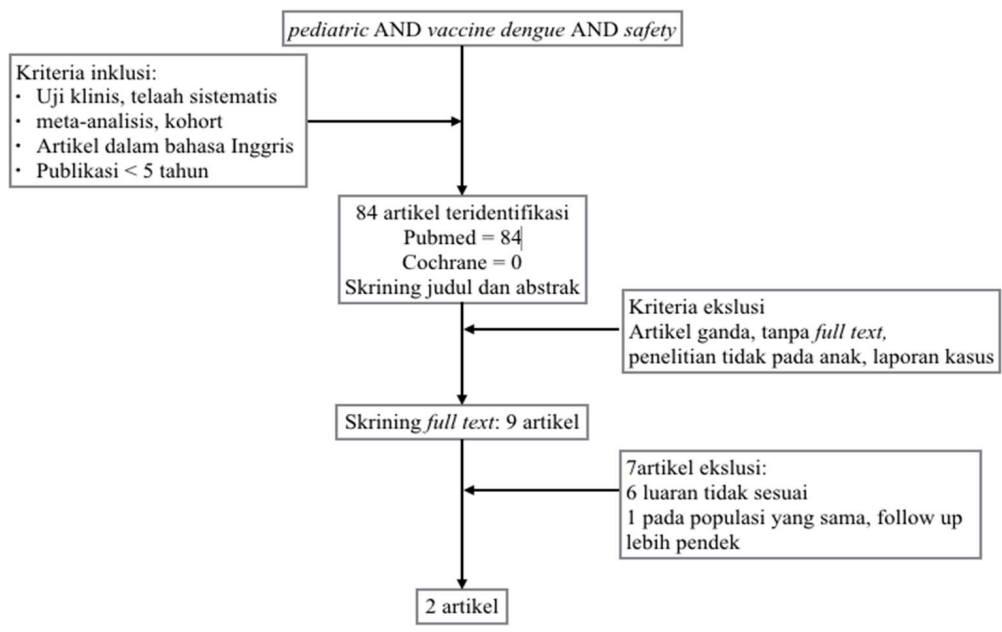

Gambar 1. Diagram alur pemilihan literatur 


\section{Hasil penelusuran literatur}

Penelitian pertama adalah studi uji klinis acak terkontrol oleh Garcia dkk. yang dipublikasikan pada tahun 2018 (level of evidence 1b). Studi ini bertujuan untuk mengetahui risiko rawat inap dan infeksi dengue berat yang terkonfirmasi secara virologis (VCD) pada pasien yang mendapat vaksin dengue dibandingkan dengan kontrol dalam kurun waktu empat tahun setelah injeksi pertama vaksin. Kriteria inklusi adalah semua sampel yang termasuk fase III uji klinis vaksin CYD-TDV, yaitu CYD14, CYD15 dan CYD 23. Sampel dirandomisasi dengan perbandingan 2:1 untuk kelompok vaksin (23.429 subyek) dan kelompok kontrol (11.694 subyek), kemudian dikelompokkan berdasarkan usia dan tempat penelitian. Kelompok intervensi mendapatkan vaksin CYD-TDV (Dengvaxia ${ }^{\circledR}$ ), sedangkan kelompok kontrol mendapat plasebo atau vaksin lain. Dua ribu peserta dari CYD14 dan CYD 15 serta 300 peserta dari CYD23 dimasukan ke dalam sub-kelompok imunogenisitas yang menjalani pemeriksaan serostauts dengue pada awal penelitian. Penelitian diikuti selama empat tahun untuk menilai efikasi serta keamanan jangka panjang. Tidak ada partisipan yang keluar dari penelitian karena efek samping serius terkait vaksin.

Luaran primer pada penelitian ini adalah risiko rawat inap karena VCD dan dengue berat secara keseluruhan, berdasarkan usia ( $\geq 9$ tahun dan $<9$ tahun yaitu 2-5 tahun dan 6-8 tahun) dan berdasarkan studi. Distribusi serotipe dengue pada kasus dengue berat dijadikan luaran sekunder. Dilakukan juga analisis terhadap risiko hospitalisasi, baik akibat VCD maupun dengue berat, berdasarkan serostatus pada subkelompok imunogenisitas.

Risiko rawat inap kasus VCD ataupun dengue berat seluruh partisipan pada tahun ke-3 dan ke- 4 adalah 0,999, 0,459 dan 0,683 pada CYD14, CYD15 dan CYD23 berturutan, dan seluruh partisipan sembuh total. Pada kelompok usia 9-16 tahun, risiko relatif rawat inap pada tahun pertama hingga ke- 4 adalah 0,324 (IK95\% 0,24-0,43), dengan risiko lebih tinggi pada tahun ke-3 dan ke-4 dibandingkan dengan tahun pertama dan kedua. Hal yang sama juga didapatkan untuk risiko dengue berat pada tahun ke-3 dan ke-4 lebih tinggi dibandingkan dengan tahun ke-1 dan ke-2 (RR:0,065, IK95\% 0,01-0,22; RR:0,752, IK95\% 0,28-2,12). Secara keseluruhan (tahun 1-4), vaksin dengue dapat mengurangi angka dengue berat sampai 75,8\% pada kelompok usia $\geq 9$ tahun.
Risiko relatif rawat inap pada resipien seropositif $<1(0,292$, IK95\% 0,14-0,58) dan pada resipien seronegatif 1,327 (IK95\% 0,56-3,48) untuk seluruh usia. Sementara untuk usia $\geq 9$ tahun, risiko relatif pada kelompok seropositif yaitu 0,243 (IK95\% 0,08-0,64) dan pada kelompok seronegatif 0,937 (IK95\% 0,244,37) dengan tujuh kasus pada resipien vaksin dan empat kasus kontrol. Penurunan risiko relatif (RRR) dengue berat pada anak usia $\geq 9$ tahun adalah $76 \%$ (RR 0,242, IK95\% 0,12-0,46). Lima partisipan seronegatif mengalami dengue berat pada kelompok vaksin, dan empat dari lima kasus adalah anak $<9$ tahun. Dengue berat terjadi pada enam individu seropositif kelompok kontrol, dan satu resipien vaksin (4/6 partisipan usia $<9$ tahun). Serotipe yang ditemukan pada kasus dengue berat pada resipien vaksin, paling banyak adalah serotipe $1(n=19)$, serotipe $2(n=16)$, serotipe 3 $(\mathrm{n}=12)$ dan serotipe $4(\mathrm{n}=2)$. Pada partisipan yang tidak divaksin, serotipe $2(n=19)$ ditemukan lebih banyak dibandingkan serotipe 1, 3, dan 4 .

Penelitian kedua merupakan penelitian case-cohort yang dilakukan oleh Sridhar dkk pada tahun 2018. Penelitian ini menganalisis ulang data yang didapat dari tiga uji klinis vaksin dengue sebelumnya (CYD14, CYD15 dan CYD23). Sebanyak 3578 partisipan dilibatkan, terbagi ke dalam 2 kelompok, yaitu 2384 kelompok vaksin dan 1194 kelompok kontrol. Seluruh kasus dengue yang terkonfirmasi secara virologis, rawat inap karena VCD, dan dengue berat dikaji berdasarkan serostatus. Sepuluh persen partisipan diambil secara acak dari masing-masing uji klinis. Sero-status awal resipien sebelum mendapat vaksin didata dan jika data tidak tersedia maka diperhitungkan berdasarkan analisis yang melibatkan beberapa variabel, termasuk titer NS1 IgG enzyme-linked immunosorbent assay (ELISA) bulan ke-13 dari sampel darah resipien yang disimpan. Digunakan dua metode perhitungan, yaitu regresi logistik untuk multiple imputation (MI) dan super-learner untuk targeted minimum loss-based estimation (TMLE).

Luaran primer yang diteliti mencakup risiko rawat inap akibat VCD pada resipien seronegatif dengan usia $\geq 9$ tahun, serta risiko yang sama dihitung berdasarkan kelompok usia sebagai luaran sekunder. Selain itu, insidens rawat inap VCD dan dengue berat (luaran keamanan) serta luaran efikasi berupa kemampuan vaksin dalam mencegah VCD simptomatik dihitung. Efikasi dievaluasi sampai 25 bulan dan keamanan diikuti hingga 4 tahun setelah fase surveilans aktif. 
Analisis exploratory menunjukkan adanya perbedaan bermakna dalam efek terapi terkait luaran keamanan dan efikasi antara serostatus ( $\mathrm{p}<0,01$ untuk semua perbandingan). Perbedaan bermakna tidak didapatkan dalam efek terapi terkait luaran keamanan antar kelompok usia (2-8 tahun dan 9-16 tahun) pada kelompok seronegatif. Hasil analisis menunjukkan diantara partisipan seronegatif usia 9-16 tahun, hazard ratio (vaksin:kontrol) hospitalisasi akibat VCD dan dengue berat berturut-turut adalah 1,41 (IK95\% 0,74-2,68), dan 2,44 (IK95\% 0,4712,56). Sedangkan pada partisipan seropositif, hazard ratio (vaksin:kontrol) hospitalisasi akibat VCD dan dengue berat berturut-turut adalah 0,21 (IK95\% 0,14-0,31) dan 0,16 (IK95\% 0,07-0,37). Insidens kumulatif rawat inap akibat VCD pada individu seronegatif selama 5 tahun adalah 1,57\% (IK95\% 1,13-2,19) pada kelompok vaksin dan 1,09\% pada kelompok kontrol. Kecendrungan risiko dengue berat yang lebih tinggi pada kelompok vaksin juga ditemukan pada kelompok individu seronegatif, insidens kumulatif dengue berat pada kelompok vaksin, yaitu $0,4 \%$ (IK95\% 0,22-0,75), sedangkan pada kelompok kontrol 0,17\% (IK95\% 0,04-0,83).

Berbeda hasilnya dengan partisipan seropositif dengan usia yang sama, ditemukan insidens rawat inap dan dengue berat pada kelompok vaksin $0,38 \%$ (IK95\% 0,26-0,54) dan 0,08\% (IK95\% 0,03-0,17). Sementara pada kelompok kontrol didapatkan angka yang lebih tinggi, yaitu 1,88\% (IK95\% 1,54-2,31) dan 0,48\% (IK95\% 0,34-0,69).

Di antara partisipan seronegatif usia 9-16 tahun, hazard ratio untuk rawat inap (vaksin: kontrol) pada bulan ke-25 dan seterusnya adalah $>1$. Berdasarkan periode waktunya, risiko rawat inap berlebih karena kasus VCD pada resipien seronegatif dimulai pada bulan ke-30. Sementara di antara partisipan seropositif, risiko kumulatif rawat inap lebih rendah pada kelompok vaksin dibandingkan dengan kelompok kontrol selama periode follow up. Efikasi vaksin untuk mencegah VCD simptomatik pada resipien seronegatif dinilai tidak bermakna (39\%, IK95\% -1-63) dan berbeda bermakna di antara resipien seropositif (76\%, IK95\% 64-84). Rangkuman penelitian tertera di Lampiran 1.

\section{Telaah kritis}

Telaah kritis dilakukan berdasarkan kriteria Oxford Centre for Evidence Based Medicine untuk studi uji klinis dan kasus-kohort (Tabel 4).

\section{Pembahasan}

Kasus kematian resipien vaksin dengue yang dikaitkan dengan dengue di Filipina pada tahun 2017 dan pencabutan izin edar vaksin dengue secara permanen oleh FDA di negara tersebut telah menimbulkan keraguan di masyarakat mengenai keamanan vaksin. ${ }^{11,12}$ Meskipun, kasus kematian tersebut tidak terbukti secara medis akibat dengue. Laporan kematian serupa tidak didapatkan di 19 negara lainnya yang telah mendapat izin edar vaksin dengue. Di Brazil, vaksin ini masih dijadikan program sub-nasional dan di Australia dan Asia Pasifik sebagai vaksin non-program.

Beberapa penelitian sudah menguji keamanan vaksin dengue hingga empat tahun setelah injeksi pertama, sebagaimana yang direkomendasikan $\mathrm{WHO}$, yaitu untuk memverifikasi bahwa respons imun terhadap vaksinasi tidak memberikan kecenderungan terhadap dengue berat dan bahwa risiko dengue berat tidak meningkat seiring waktu akibat berkurangnya titer antibodi yang diinduksi vaksin pada individu yang kekebalannya belum meningkat secara alami. Pada dua penelitian ini penanda pengganti keamanan yang digunakan adalah risiko rawat inap pada dengue yang terkonfirmasi secara virologis serta dengue berat.

Respons vaksin pada setiap individu berbeda, beberapa faktor yang memengaruhi diantaranya adalah usia, infeksi lampau dan transmisi dengue di masingmasing daerah atau negara. Penelitian di Singapura dan Vietnam, menyatakan titer antibodi terhadap dengue lebih tinggi dan bertahan lebih lama pada resipien vaksin dengan baseline seropositif terutama pada usia $\geq 9$ tahun. ${ }^{13,14}$ Pada penelitian di Asia Pasifik, termasuk Vietnam dan Amerika, resipien seropositif menunjukkan geometric mean titer (GMT) dengue yang lebih tinggi pada tahun ke-4 setelah dosis ketiga vaksin, dan pada daerah dengan endemisitas dengue tinggi titernya tidak menurun.

Vaksinasi dengue pada individu seropositif memberikan proteksi jangka panjang terhadap dengue simptomatik, sedangkan pada individu sero-negatif terdapat periode transisi saat pasien memiliki risiko lebih tinggi untuk mengalami rawat inap akibat infeksi dengue atau dengue berat. Penelitian Hadinegoro $\mathrm{dkk}^{15}$ menyatakan vaksin dapat mencegah dengue berat (kriteria IDMC) dan demam berdarah dengue (WHO 1997) pada resipien seropositif sekitar 93,2\% dan 92,9\%. Resipien seronegatif tidak mendapatkan proteksi yang signifikan. Pada kedua penelitian ini, 
Tabel 4. Telaah kritis (1)

\begin{tabular}{|c|c|}
\hline $\begin{array}{l}\text { Artikel } \\
\text { Desain } \\
\text { Level of evidence }\end{array}$ & $\begin{array}{l}\text { Garcia dkk }^{17} \\
\text { Uji klinis acak terkontrol } \\
1 \mathrm{~b}\end{array}$ \\
\hline Validitas & $\begin{array}{l}\text { 1.a. Randomisasi } \\
\text { Randomisasi dengan alokasi CYD-TDV:kontrol (plasebo/vaksin lain) 2:1 } \\
\text { 1.b. Karakteristik subyek } \\
\text { Tidak ada perbedaan signifikan pada kelompok intervensi dan kontrol (CYD14, CYD15, CYD23) } \\
\text { 2.a. Perlakuan } \\
\text { Kedua kelompok diperlakukan sama selain intervensi yang diberikan. } \\
\text { 2.b. Analisis } \\
\text { Analisis efikasi dilakukan secara per-protokol. Loss to follow up <20\% } \\
\text { Analisis deskriptif dilakukan pada populasi yang diuji keamanan vaksinnya yaitu seluruh resipien yang } \\
\text { menerima minimal satu kali dosis vaksin (intention to treat). Data dipresentasikan dalam jumlah kasus, } \\
\text { insidens per tahun, risiko relatif dengan IK95\%. } \\
\text { 3.a. Penyamaran } \\
\text { Dilakukan penyamaran ganda pada partisipan dan peneliti } \\
\text { Kesimpulan: sahih }\end{array}$ \\
\hline Kepentingan & 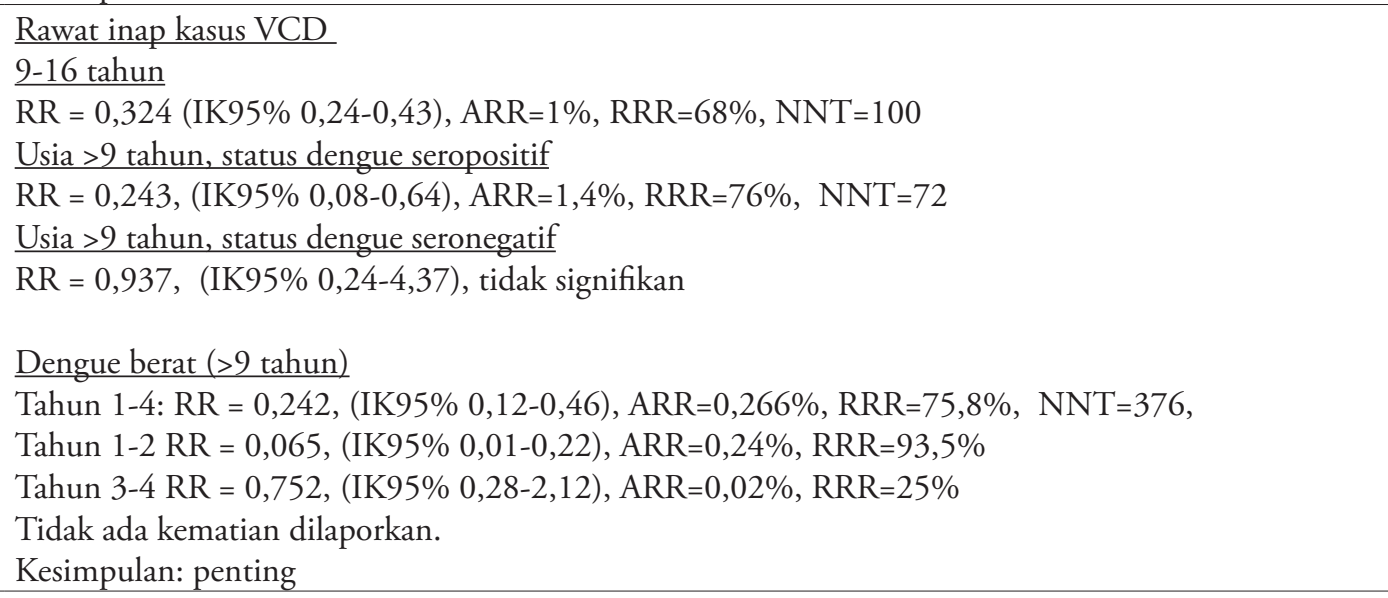 \\
\hline Penerapan & $\begin{array}{l}\text { Apakah sama dengan kondisi pasien? Ya } \\
\text { Apakah intervensi bisa dilakukan di tempat saya bekerja? Ya } \\
\text { Apakah keuntungan lebih besar dibandingkan kerugian? Ya, untuk resipien dengan serostatus positif } \\
\text { Kesimpulan: dapat diterapkan }\end{array}$ \\
\hline
\end{tabular}

kelompok dengue seropositif memiliki risiko rawat inap dan dengue berat yang konsisten berada $<1$, artinya vaksin dengue bersifat protektif. ${ }^{15-17}$ Risiko rawat inap dan dengue berat antara resipien vaksin seronegatif dibandingkan dengan kontrol tidak bermakna baik secara statistik maupun secara klinis. Hal lain yang perlu diperhatikan adalah insidens rawat inap dan dengue berat pada resipien seronegatif keduanya meningkat jika dibandingkan dengan kontrol, tetapi jika dibandingkan dengan kelompok seropositif yang tidak mendapat vaksin adalah sama. ${ }^{16,17}$ Teori antibody dependent enhancment (ADE) dipostulasikan berhubungan dengan fenomena ini. Tidak ada data yang menyatakan bahwa manifestasi klinis dengue resipien seronegatif lebih berat dibandingkan dengan individu seropositif yang tidak mendapat vaksin. ${ }^{8}$

Pada tingkat populasi, keuntungan vaksinasi akan melebihi risiko individu seronegatif jika vaksin diberikan pada daerah dengan transmisi dengue tinggi dan dalam jangka waktu yang lama sampai efek proteksi tidak langsung didapatkan. ${ }^{12}$ Penelitian Prayitno $\mathrm{dkk}^{18}$ mengenai seroprevalens dengue di Indonesia, memperlihatkan lebih dari $80 \%$ anak usia $\geq 10$ tahun dan $89 \%$ usia $>15$ tahun pernah mengalami 
Tabel 4. Telaah kritis (2)

\begin{tabular}{|c|c|}
\hline $\begin{array}{l}\text { Artikel } \\
\text { Desain } \\
\text { penelitian } \\
\text { Level of evidence }\end{array}$ & $\begin{array}{l}\text { Shridar dkk }{ }^{16} \\
\text { Case-cohort } \\
\text { 2.b }\end{array}$ \\
\hline Validitas & $\begin{array}{l}\text { Apakah individu yang dijadikan sampel diikuti sejak awal terdiagnosisnya penyakit? Ya } \\
\text { Apakah follow-up dilakukan cukup panjang? Ya, pasien diikuti selama lima tahun dan pengamatan } \\
\text { akan dilanjutkan sampai tahun ke-6 } \\
\text { Apakah penilaian kriteria luaran objektif? Ya, kriteria luaran dinilai berupa kasus dengue yang } \\
\text { terkonfirmasi dari pemeriksaan darah } \\
\text { Apakah dilakukan penyesuaian terhadap faktor prognostik yang penting? Ya, penelitian ini } \\
\text { diklasifikasikan berdasarkan usia dan status serologis } \\
\text { Kesimpulan: sahih }\end{array}$ \\
\hline Kepentingan & $\begin{array}{l}\text { Usia 9-16 tahun } \\
\text { Resipien seronegatif } \\
\text { RR (rawat inap VCD, VCD berat): 1,41 (IK95\% 0,74-2,68); 2,44 (IK95\% 0,47-12,56), tidak } \\
\text { signifikan } \\
\text { Resipien seropositif } \\
\text { RR rawat inap VCD: } 0,21 \text { (IK95\% 0,14-0,31), ARR 15\% RRR 79\% } \\
\text { RR VCD berat: 0,16 (IK95\% 0,07-0,37), ARR 3,8\%, RRR 84\% } \\
\text { Insidens kumulatif, individu seronegatif } \\
\text { Rawat inap (vaksin,kontrol): 1,57\% (IK95\% 1,13-2,19); 1,09\% (IK95\% 0,53-2,27) } \\
\text { VCD berat (vaksin:kontrol): 0,4\% (IK95\% 0,22-0,75); 0,17\% (IK95\% 0,04-0,83) } \\
\text { Insidens kumulatif, individu seropositif } \\
\text { Rawat inap (vaksin,kontrol): 0,38\% (IK95\% 0,26-0,54); 1,88\% (IK95\% 1,54-2,31) } \\
\text { VCD berat (vaksin,kontrol): 0,08\% (IK95\% 0,03-0,17); 0,48\% (IK95\% 0,34-0,69) } \\
\text { Efikasi vaksin } \\
\text { Seropositif: 76\%(IK95\% 64-84), ARR 40\% } \\
\text { Seronegatif: 39\%(IK95\% -1-63), tidak signifikan } \\
\text { Tidak ada kematian dilaporkan } \\
\text { Kesimpulan: penting }\end{array}$ \\
\hline Penerapan & $\begin{array}{l}\text { Apakah sama dengan kondisi pasien? Ya } \\
\text { Apakah intervensi bisa dilakukan di tempat saya bekerja? Ya } \\
\text { Apakah keuntungan lebih besar dibandingkan kerugian? Ya, untuk resipien dengan serostatus positif, } \\
\text { untuk resipien dengan serostatus negatif tidak ada perbedaan bermakna } \\
\text { Kesimpulan: dapat diterapkan }\end{array}$ \\
\hline
\end{tabular}

infeksi dengue minimal satu kali. Jika estimasi risiko dengue berat dikumulatifkan pada 1 juta anak usia 9-16 tahun di Indonesia, dalam periode 5 tahun vaksin dapat mencegah sekitar 11.000 rawat inap, dan 2500 dengue berat. Nilai vaksin dengue untuk kesehatan masyarakat perlu dipertimbangkan dengan tidak mengabaikan risiko individu.

Kelemahan dari dua penelitian di atas adalah definisi dengue berat yang digunakan pada penelitian sesuai dengan kriteria IDMC, sedangkan klinisi menggunakan klasifikasi WHO 1997. Spektrum klinis, derajat keparahan penyakit dengue pada kriteria
IDMC sangat luas dan berbeda. IDMC menyebut dengue berat pada kondisi: 1. Trombosit di bawah 100.000/ul dengan perdarahan (uji torniket, petekie atau perdarahan lainnya) ditambah dengan kebocoran plasma, 2. Renjatan dengue 3. Perdarahan yang membutuhkan transfusi, 4. Ensefalopati, 5. Gangguan hepar, 6. Gangguan fungsi ginjal, 7. Perikarditis, miokarditis dan gagal jantung. ${ }^{16}$ Pada studi-studi tersebut, sebagian besar pasien yang diklasifikasikan dengue berat adalah sesuai kategori satu. Klasifikasi WHO 1997 memasukannya ke dalam derajat I atau II dan bukan diklasifikasikan sebagai dengue berat. ${ }^{1}$ 
Seluruh resipien vaksin yang mengalami dengue berat sesuai kriteria IDMC tidak ada yang meninggal dan pasien pulih kembali. Seluruh penelitian tidak melaporkan adanya kasus kematian yang berhubungan kausa dengan pemberian vaksin. ${ }^{16,17}$

Seluruh hasil penelitian di atas mendukung rekomendasi WHO SAGE pada bulan April 2018 yang memfokuskan pemeriksaan serostatus (IgG) pada calon resipien vaksin, dan jika akan digunakan secara masal (program nasional) maka survei seroprevalens harus dilakukan. ${ }^{9}$ Pada akhirnya, vaksin dengue harus diberikan dengan memperhatikan cost benefit dan harus terintegrasi dengan strategi pengendalian dengue yang meliputi pemberantasan vektor, tata laksana kasus dengan tepat berdasarkan bukti ilmiah, partisipasi masyarakat dan penguatan sistem surveilans infeksi dengue. $^{3}$

\section{Kesimpulan}

Pemberian vaksin dengue pada individu seronegatif usia sembilan tahun ke atas tidak memengaruhi risiko rawat inap dan dengue berat secara signifikan.

\section{Saran}

Pemberian vaksin dengue pada anak harus dilakukan secara hati-hati dengan memperhatikan usia dan status serologi. Diperlukan penelitian lebih lanjut yang menggunakan kriteria derajat dengue sesuai dengan yang diaplikasikan klinisi pada praktik sehari-hari, yaitu klasifikasi WHO 1997. Selain itu, diperlukan pengamatan jangka panjang untuk melihat lebih jauh profil keamanan vaksin.

\section{Daftar pustaka}

1. SEARO. Comprehensive guidelines for prevention and control of dengue and dengue haemorrhagic fever. WHO SEARO; 2011.

2. WHO, editor. Global strategy for dengue prevention and control, 2012-2020. Geneva: WHO Press; 2012.

3. Hadinegoro SR, Satari HI. Dengue. Dalam: Gde Ranuh IGN, Suyitno H, Hadinegoro SR, Kartasasmita CB, Ismudijanto, Seodjatmiko, penyunting. Pedoman Imunisasi di Indonesia. Edisi ke-6. Jakarta: Badan Penerbit IDAI;2017.h.404-10.
4. Horstick O, Runge-Ranzinger S, Nathan MB, Kroeger A. Dengue vector-control services: how do they work? A systematic literature review and country case studies. Trans Royal Soc Trop Med Hyg 2010;10:379-86.

5. Capeding MR, Tran NH, Hadinegoro SR, dkk. Clinical efficacy and safety of a novel tetravalent dengue vaccine in healthy children in Asia: a phase 3, randomised, observermasked, placebo-controlled trial. Lancet 2014;384:1358-65.

6. Guy B, Noriega F, Ochiai L, dkk. A recombinant live attenuated tetravalent vaccine for the prevention of dengue. Expert Rev Vaccines 2017;10:1-13.

7. Guy B, Briand O, Lang J. Development of the Sanofi Pasteur tetravalent dengue vaccine: one more step forward. Vaccine 2015;33:7100-11.

8. World Health Organization. Updated questions and answers related to the dengue vaccine Dengvaxia ${ }^{\oplus}$ and its use. 2017. Diakses tanggal 16 April 2019. Didapat dari: http://www.who. int/immunization/diseases/denguelq_and_a_dengue_vaccine_ dengvaxia_uselen/.

9. World Health Organization. Revised SAGE recommendation on use of dengue vaccine. Diakses tanggal 10 April 2019. Didapat dari: http://www.who.int/immunization/diseases/ denguel revised_SAGE_recommendations_dengue_vaccines_ apr2018/en/).

10. Badan pengawas obat dan makanan Republik Indonesia. Penjelasan badan POM RI terkait isu keamanan vaksin dengue (demam berdarah). Diakses tanggal 10 April 2019. Didapat dari: https://www.pom.go.id/new/view/more/klarifikasi/79/ penjelasan-badan-pom-ri-terkait-isu-keamanan-vaksin-dengue-demam-berdarah-.html.

11. Fatima K, Syed NI. Dengvaxia controversy: impact on vaccine hesitancy. J Glob Health 2018;8:1-3.

12. Coudeville L, Baurin N, Botello GO. Assesment of benefits risks associated with dengue vaccination at the individual and population levels: a dynamic modeling. Expert Rev Vaccines 2018;17:1-11.

13. Tran NH, Chansinghakul D, Chong CY, dkk. Long-term immunogenicity and safety of tetravalent dengue vaccine (CYD-TDV) in healthy populations in Singapore and Vietnam: 4-year follow-up of randomized, controlled, phase II trials. Hum Vaccines Immunother 2019;1:1-14.

14. Rosa BR, Cunha AJ, Medronho RA. Efficacy, immunogenicity and safety of a recombinant tetravalent dengue vaccine (CYDTDV) in children aged 2017 years: systematic revies and meta-analysis. BMJ Open 2019;9:1-9.

15. Hadinegoro SR, Arredondo-García JL, Capeding MR. Efficacy and long-term safety of a dengue vaccine in regions of endemic disease. N Engl J Med Overseas Ed 2015;373:1195-206.

16. Shridar S, Luedtke A, Langevin E, dkk. Effect of dengue 
serostatus on dengue vaccine safety and efficacy. N Engl J Med 2017;4:1-14.

17. Garcia JL, Hadinegoro SR, Reynales H, dkk. Four-year safety follow up of the tetravalent dengue vaccine efficacy randomized controlled trials in Asia and Latin America. Clin Microbiol
Infect 2018:24:755-63.

18. Prayitno A, Taurel AF, Nealon J, dkk. Dengue seroprevalence and force of primary infection in a representative population of urban dwelling Indonesian children. PLoS Negl Trop Dis 2017;11:1-16.

Lampiran 1. Rangkuman studi

\begin{tabular}{|c|c|c|}
\hline Nama studi/ & Garcia dkk. ${ }^{17} 1 \mathrm{~b}$ & Shridar dkk. ${ }^{16} 2 \mathrm{~b}$ \\
\hline desain & Uji klinis acak terkontrol & Case-cohort \\
\hline Tahun & 2011-2018 & 2018 \\
\hline Lokasi & $\begin{array}{l}\text { Lima negara Amerika Latin (CYD-14), } 5 \text { negara Asia Pasifik } \\
\text { (CYD-15), Thailand (CYD-57/23) }\end{array}$ & $\begin{array}{l}\text { Lima negara Amerika Latin, } 5 \text { negara Asia Pasifik, } \\
\text { Thailand }\end{array}$ \\
\hline Tujuan & $\begin{array}{l}\text { Mengetahui risiko rawat inap dan infeksi dengue yang } \\
\text { terkonfirmasi virologi serta dengue berat pada pasien yang } \\
\text { mendapatkan vaksin dengue dibandingkan kontrol dalam } \\
\text { kurun waktu } 4 \text { tahun sejak injeksi dosis pertama. }\end{array}$ & $\begin{array}{l}\text { Menilai risiko rawat inap kasus dengue terkonfirmasi } \\
\text { virologi pada resipien seronegatif }\end{array}$ \\
\hline Kriteria inklusi & $\begin{array}{l}\text { Fase III uji klinis vaksin CYD-TDV: CYD14 (partisipan } \\
\text { usia 2-14 tahun), CYD15 (partisipan usia 9-16 tahun) dan } \\
\text { fase IIb CYD23 (partisipan usia 4-11 tahun) }\end{array}$ & $\begin{array}{l}\text { Subjek diambil secara random dari } 3 \text { uji klinis }(10 \% \\
\text { subjek dari masing-masing uji klinis) }\end{array}$ \\
\hline Partisipan & $\begin{array}{l}\text { Penelitian keamanan: Kelompok intervensi } 23.429 \text { subyek } \\
\text { dipilih secara acak dan kelompok kontrol } 11.694 \text { subyek. } \\
\text { Penelitian imunogenisitas: Kelompok intervensi } 2856 \text { dan } \\
1420 \text { kelompok kontrol. } \\
\text { Tidak ada partisipan yang drop out karena efek samping } \\
\text { serius }\end{array}$ & $\begin{array}{l}3578 \text { subyek untuk analsis sub-kohort } \\
\text { - } 2384 \text { kelompok vaksin } \\
\text { - } 1194 \text { kelompok kontrol }\end{array}$ \\
\hline Intervensi & $\begin{array}{l}\text { Kelompok intervensi: Pemberian CYD-TDV (Dengvaxia®) } \\
\text { Kelompok kontrol: CYD14 dan } 15 \text { mendapatkan } \mathrm{NaCl} \\
0,9 \% \text { (plasebo), CYD23 mendapatkan 0,9\% dan } 50 \\
\text { partisipan pertama mendapatkan vaksin rabies (Verorab®) }\end{array}$ & $\begin{array}{l}\text { Kelompok risiko: resipien vaksin } \\
\text { Kelompok kontrol: partisipan tidak divaksin }\end{array}$ \\
\hline Luaran & $\begin{array}{l}\text { Luaran primer: } \\
\text { Risiko rawat inap dengan VCD dan dengue berat secara } \\
\text { keseluruhan, berdasarkan kriteria usia ( } \geq 9 \text { tahun dan }<9 \\
\text { tahun - 2-5 tahun, 6-8 tahun), dan berdasarkan studi. } \\
\text { Risiko relatif rawat inap VCD (semua derajat) berdasarkan } \\
\text { baseline serostatus pada kelompok imunogenisitas } \\
\text { Luaran sekunder: } \\
\text { Distribusi serostatus pada pasien dengue berat. }\end{array}$ & $\begin{array}{l}\text { Luaran primer: } \\
\text { Risiko rawat inap dengan VCD pada resipien } \\
\text { seronegatif vaksin usia } 9 \text { tahun atau lebih. } \\
\text { Luaran keamanan: insidens rawat inap kasus VCD dan } \\
\text { dengue berat dalam follow up } 5 \text { tahun. } \\
\text { Luaran sekunder: } \\
\text { Risiko rawat inap dengan VCD pada resipien } \\
\text { seronegatif vaksin berdarkan kelompok usia. } \\
\text { Luaran efikasi: efikasi vaksin untuk mencegah VCD } \\
\text { simptomatik sampai } 25 \text { bulan pada pasien seronegatif }\end{array}$ \\
\hline Bias & Bias follow up, bias alokasi & Bias follow up, bias alokasi \\
\hline
\end{tabular}

